\title{
Визначення впливу занять з веслування на каное на фізіологічні вигини хребта спортсменів
}

\author{
Ю. І. Павлішен, О. О. Солтик
}

\author{
Клінічна лікарня, м. Хмельницький, Україна \\ Хмельницький національний університет, м. Хмельницький, Україна
}

\begin{abstract}
Резюме. Подано характеристику изгибов позвоночника в сагиттальной плоскости у спортсменов, занимающихся греблей на каноэ. Установлено, что систематические занятия спортом приводят к появлению определенных осложнений опорно-двигательного аппарата, связанных с искривлением позвоночника. Обнаружено, что у гребцов наиболее увеличены изгибы позвоночника в грудном отделе, что указывает на наличие круглой спины.

Ключевые слова: физиологические изгибы позвоночника, осанка, гребля на каноэ.
\end{abstract}

\begin{abstract}
Summary. The characteristics of curves of the spine in the sagittal plane in athletes involved in canoeing are presented. We revealed that systematic sport activity give rise to certain disorders of the musculoskeletal system associated with abnormal curvature of the spine. It was found that, in canoe rowers, curvature of the spine increased most of all in the thoracic region which indicates the development of kyphosis.
\end{abstract}

Keywords: physiological curvature of the spine, posture, canoeing.

Постановка проблеми. Розглядаючи спортивну діяльність як один із унікальних видів рухової активності, що здійснюється на межі психічних $\mathrm{i}$ фрізіологічних можливостей людини, багато науковців поглиблюють знання про людину з позицій медицини, фрізіології, біомеханіки, анатомії, спортивної морфології тощо. Серед важливих проблем, які досі не знайшли повного і всебічного висвітлення, залишається питання, пов'язане із впливом значних фрізичних навантажень на організм спортсмена, зокрема на формування постави. Однією з головних ознак правильної постави $\epsilon$ наявність фрізіологічних вигинів хребта, що сприяють рівномірному розподілу навантаження на хребет, пом'якшують поштовхи й удари під час руху, запобігають виникненню зміщення і захворюваності внутрішніх органів тощо. Водночас існує дефріцит наукових робіт, у яких охарактеризовано вплив окремих видів спорту, зокрема веслування на каное, на формування фрізіологічних вигинів хребта спортсмена. Дана обставина обумовлює актуальність і потребу в проведенні подальших досліджень.

Аналіз останніх досліджень і публікацій. Результати багатьох наукових досліджень свідчать про наявність тісного зв'язку між фрізичними навантаженнями та формуванням постави людини. У працях багатьох учених $[3,10,12]$ підтверджується залежність постави спортсмена від особливостей різних видів спорту, причому підкреслюється наявність як позитивного, так і негативного їх впливу.
Деякі дослідники [6], визначаючи основні чинники, що обумовлюють вигини хребта, поряд із віком та статевими відмінностями особливе значення надають руховій активності.

Для проведення аналізу впливу виду спорту на поставу учня було запропоновано виділяти наступні показники: характеристики руху, вплив його на опорно-руховий апарат, раціональність по відношенню до постави [5].

Вагомими в питанні дослідження постави $\epsilon$ наукові результати, у яких запропоновано методику встановлення кількісної оцінки рухливості хребта, що дозволяє також точно встановити стан фрізіологічних вигинів хребта [8].

Разом з тим результати вивчення спеціальної літератури дозволяють зробити висновок про те, що переважна більшість досліджень пов'язана із проблемою погіршення стану хребта, викликаною зменшенням рухового режиму, обсягу фрізичних навантажень, зниженням рухової активності (гіпокінезія), що має ряд негативних наслідків. Дефріцит рухової активності призводить до недостатньої стимуляції росту і розвитку організму, появи зайвої маси тіла за рахунок відкладення жирової тканини. Обмеження обсягу м'язової діяльності веде до суттєвого зниження арерентної імпульсації м'язів, що призводить до зниження їхньої скорочувальної властивості. В м'язових волокнах спостерігаються виразні атрофрічні та дистрофрічні зміни, суттєво зменшуються сила і тонус м'язів, відбуваються порушення 
рухових навичок та координації рухів [11]. Усе це чинить негативний вплив на формування постави. Зазначимо, що відомі поодинокі наукові роботи, де розглянуто вплив значного за обсягом і інтенсивністю фрізичного навантаження, асиметричності фрізичних вправ на характер формування постави.

Було здійснено спроби провести класифікацію видів спорту за характером їх впливу на опорно-руховий апарат спортсмена [4]. У зв'язку із цим усі види спорту було розподілено на: симетричні, при яких ліва і права частини тіла виконують одночасно чи поперемінно одні і ті самі рухи та дії; асиметричні, при яких частини тіла виконують різні рухи; змішані, в яких відбувається поєднання чи поперемінна зміна симетричних і асиметричних навантажень.

Хочемо відмітити, що цікавими з наукової точки зору стають дослідження, в яких визначають вплив занять веслуванням на каное на фрормування фрізіологічних вигинів хребта спортсменів.

Мета дослідження - визначення особливостей фрормування фрізіологічних вигинів хребта спортсменів, які займаються веслуванням на каное.

Методи дослідження: теоретичний аналіз спеціальної літератури, метод визначення вигинів хребта за допомогою методики за Гамбурцевим В. О. [1].

Результати дослідження та їх обговорення. Для хребта у сагітальній площині характерні основні фрізіологічні вигини: шийний і поперековий лордози; грудний і крижово-куприковий кіфози. В міру виразні фрізіологічні вигини хребта, що відповідають нормам і віковим характеристикам, є ознакою доброї постави, здорового хребта. Будь-яке відхилення, пов'язане як зі збільшенням, так і зі зменшенням вигинів у даній площині, вказує на наявність певних захворювань.

Головними ознаками, якими характеризується правильна або добра постава, є: розташування на одній осі тулуба та голови; симетричне розташування плечей, кутів лопаток, сідничних складок, трикутників талії; симетрія шийно-плечових ліній; у міру виразні фрізіологічні вигини хребта (лордози і кіфози); однакове розташування акроміальних точок у фрронтальній площині, пропорційна довжина нижніх і верхніх кінцівок, правильне положення ступень. На поставу також мають вплив форми грудної клітки, рук та ніг тощо [2, 9]. Серед зазначених ознак, що характеризують правильну поставу, у своєму дослідженні ми обрали фрізіологічні вигини хребта як такі, що найбільше формують зовнішній вигляд людини та забезпечують стан іï опорно-руховому апарату.
Для проведення дослідження 3 визначення впливу спортивної діяльності на стан вигинів хребта спортсменів у веслуванні на каное було відібрано групу обстежуваних. До неї увійшли чоловіки віком 16-30 років, які спеціалізуються у веслуванні на каное. Основною вимогою під час комплектування групи була висока спортивна кваліфікація (рівень спортивної майстерності відповідав кандидату в майстри спорту та майстру спорту) та значний спортивний стаж. Усі спортсмени, які взяли участь у обстеженні, входять до складу збірної команди Хмельницької області 3 веслування на байдарках та каное. Загальна кількість спортсменів - 21 особа.

Аналіз спортивної діяльності у веслуванні на байдарках та каное дозволяє визначити ряд особливостей, що вказують на асиметричність фрізичного навантаження. Біомеханічний аналіз виявив нерівномірність виконання рухів певними сегментами (біоланками) спортсмена.

Найбільше задіяні в роботі верхня частина тіла (тулуб, пояс верхніх кінцівок) [7]. На відміну від байдарочника, у якого основна поза сидяча, каноїст стоїть у човні постійно на одному коліні (лівому чи правому). Спортсмени тривалий час знаходяться в асиметричній позі. Окрім цього, хребет постійно здійснює одноманітні рухи нахил уперед, що притаманно для каноїстів, а також відбувається скручування навколо вертикальної осі, характерне для каноїстів та байдарочників. Як наслідок цього - одна половина тіла отримує більше навантаження, ніж інша.

Характер навантаження - тривалий, середньої інтенсивності. Кваліфіковані веслувальники, як правило, мають два-три разових щоденних тренування, з яких спеціальна робота (веслування на воді, знаходячись у човні) може досягати до 4 год. на добу.

Зважаючи на тривале фрізичне навантаження, здебільш асиметричного характеру, неспецифічне положення тіла під час веслування, ми зробили припущення, що ці обставини можуть відбитись на формуванні постави, зокрема на стані фрізіологічних вигинів хребта.

3 огляду на сказане, було проведено емпіричне дослідження стану фрізіологічних вигинів хребта у сагітальній площині, відносно якої специоріка рухів у веслуванні на каное пов'язана з найбільшою асиметрією.

Для визначання значень вигинів хребта було використано найпоширенішу методику за Гамбурцевим В. О. [1] з використанням штангенциркуля гоніометричного типу. Суть даної методики полягає у визначенні кутів нахилу ліній хребта, утворених п'ятьма точками: A - найбільш 
виступаюча точка зовнішнього потиличного піднесення; Б - найглибша точка в ділянці шийного лордозу (зазвичай відповідає остистому відростку V шийного хребця); В - найбільш виступаюча назад точка грудного кіфозу (частіше знаходиться на рівні VII грудного хребця); Д найбільш заглиблена точка в ділянці поперекового лордозу, E - найбільш виступаюча назад точка куприка по задній середній лінії.

Для більшої точності та зручності виконання замірів визначені точки позначають на тілі людини дермографрічним олівцем. Після цього за допомогою штангенциркуля (ніжки поперемінно розташовують на відмічені точки) визначають кути нахилу сегментів хребта, розташованого між зазначеними точками. Кути визначають між даними сегментами і вертикальною площиною.

У результаті отримуємо чотири кути: кут а: між точками А і Б; кут у: між точками Б і В; кут $\beta$ : між точками В і Д; кут б; між точками Д і Е. Сума кутів а й у визначає шийний лордоз, у і $\beta$ грудний кіфоз, $\beta$ і $\sigma-$ поперековий лордоз.

Знаючи кути нахилу до вертикалі хребетного стовпа, можна дати характеристику шийного лордозу, грудного кіфозу і поперекового лордозу.

Найбільш важливими й інформативними стають показники грудного кіфозу і поперекового лордозу, оскільки вони займають більшу частину хребта і переважною мірою визначають його загальну форму.

Користуючись даною методикою при проведенні вимірювань вигинів хребта у спортсменів, було отримано експериментальні дані, занесені до таблиці 1.

Отримавши результати вигинів хребта, що характеризують стан грудного кіфозу і поперекового лордозу у каноїстів, було проведено порівняння 3 нормами, в результаті яких встановлено відхилення. Величина відхилень характеризувала ступінь збільшення чи зменшення вигинів хребта, що вказувало на відповідні захворювання.

Наведені дані свідчать, що найбільше відхилення спостерігається у грудному відділі хребта і пов'язане зі збільшенням вигинів. Користуючись

ТАБЛИЦЯ 1 - Значення фізіологічних вигинів хребта у каноїстів

\begin{tabular}{|l|c|c|}
\hline \multicolumn{1}{|c|}{\begin{tabular}{c}
\multicolumn{1}{|c|}{ Відділ } \\
хребта
\end{tabular}} & $\begin{array}{c}\text { Середнє значення, } \\
\text { градуси }\end{array}$ & $\begin{array}{c}\text { Середнє значення } \\
\text { відхилень від норми, } \\
\text { градуси }\end{array}$ \\
\hline $\begin{array}{l}\text { Грудний (грудний } \\
\text { кіфоз) }\end{array}$ & 34,86 & 5,4975 \\
\hline $\begin{array}{l}\text { Поперековий (попе- } \\
\text { рековий лордоз) }\end{array}$ & 25 & 2,225 \\
\hline
\end{tabular}

даними методики за Гамбурцевим В. О., де відхилення від норми у грудному відділі до $4^{\circ} \epsilon$ незначним, до $8^{\circ}$ - помірним і більше $8^{\circ}-$ значним та у поперековому відділі до $3^{\circ}-$ незначним, до $7^{\circ}$ - помірним і більше $7^{\circ}$ - значним, усіх обстежуваних було розподілено на групи за ступенем відхилень (табл. 2).

Аналізуючи отримані результати, можна відмітити, що у грудному відділі хребта незначні відхилення було зафріксовано лише у трьох осіб, що становить 14,29 \% обстежуваних, у п'яти каноїстів зафіксовано значний рівень відхилень $(23,81 \%)$, та найбільша кількість спортсменів 13 осіб $(61,9 \%)$ - мали помірний рівень відхилень.

Дещо кращі результати було отримано під час обстеження поперекового відділу хребта при визначенні поперекового лордозу. Лише у двох осіб було встановлено значне відхилення, третя частина каноїстів мала помірний рівень, і у 12 чоловік $(57,14 \%)$ не було виявлено значних відхилень.

У ході дослідження вигинів хребта одночасно у грудному і поперековому відділах було встановлено, що переважна більшість обстежуваних $(42,86 \%)$ мають ознаки круглої спини та третина $(33,33 \%)$ - ознаки кругло-ввігнутої.

Отримані експериментальні дані вказують на існування залежності впливу спорту на формування постави веслувальників, зокрема стан фрізіологічних вигинів хребта. При цьому відмічаємо те, що тривалі фрізичні навантаження у веслуванні на каное мають негативний вплив і характеризуються їх збільшенням здебільшого у грудному відділі.

\section{Висновки.}

1. Виявлено негативний вплив тренувальних занять з веслування на каное на фрормування постави каноїстів, що проявляється у збільшенні фрізіологічних вигинів хребта.

2. Найбільш поширеними захворюваннями постави у кваліфікованих каноїстів зафіксовано круглу та кругло-ввігнуту спини.

Перспективи подальших пошуків. Припущення про те, що тренування 3 веслування на

ТАБЛИЦЯ 2 - Розподіл осіб за ступенем відхилень вигинів хребта $(\mathrm{n}=21)$

\begin{tabular}{|l|c|c|c|}
\hline \multicolumn{1}{|c|}{ Відділ хребта } & \multicolumn{3}{|c|}{ Ступінь відхилення, \% } \\
\cline { 2 - 4 } & незначний & помірний & значний \\
\hline $\begin{array}{l}\text { Грудний (грудний } \\
\text { кіфоз) }\end{array}$ & 14,29 & $61,9^{\circ}$ & 23,81 \\
\hline $\begin{array}{l}\text { Поперековий (попереко- } \\
\text { вий лордоз) }\end{array}$ & 57,14 & 33,33 & 9,53 \\
\hline
\end{tabular}


каное призводять до виникнення захворювань у спортсменок, пов'язаних зі збільшенням вигинів хребта, спонукають до продовження подальших наукових досліджень. Головним завданням стає необхідність внесення коректив у навчально-тренувальний процес каноїстів, зокрема

\section{Література}

1. ГамбуриеВ В. А. Гониометрия человеческого тела (динамическая соматометрия) / В. А. Гамбурцев. - М.: Медицина, 1972. - С. 6-12, 14-26.

2. ДорохоВ Р. Н. Спортивная морфология: учебн. пособие для выс. и сред. спец. заведений фриз. культуры / Р. Н. Дорохов, В. Губа. - М.: СпортАкадемПресс, 2002. 236 c.

3. Дубровский В. И. Спортивная физиология / В. И. Дубровский. - М.: Гуманит. Изд. центр ВЛАДОС, 2005. 462 c.

4. Егоров Г. Е. Классификация видов спорта по характеру их влияния на опорно-двигательный аппарат спортсмена и некоторые рекомендации по рациональной ориентации детей в спорте / Г. Е. Егоров // Актуальные вопросы травматологии и ортопедии. - Л., 1983. - С. 105-107.

5. ЗабалуеВа T. В. Профилактика и коррекция нарушений осанки школьников на занятиях различными видами спорта / Т. В Забалуева // Учен. записки ун-та им. П. Ф. Лесгафта. - СПб., 2007. - Вып: 9 (31). C. $41-45$.

6. ИВаноßа E. М. Антропологические особенности изучения осанки у детей и взрослых: автореф. дис. на соискание учен. степени канд. биолог. наук: спец. 03.03.02. «Антропология по биологическим наукам» / Е. М. Иванова. - М., 2011. - 24 с

7. Иссурин В. Б. Биомеханика гребли на байдарках и каноэ / В. Б. Иссурин; под ред. В. М. Зациорского. - М.: Физкультура и спорт, 1986. - 112 с.

8. Кашуба В. А. Биомеханика осанки / В. А. Кашуба. - К. Олимп. лит., 2003. -280 с.

9. Никитюк Б. А. Анатомия и спортивная морфология (практикум): учеб. пособие для ин-тов фриз. культуры / Б. А. Никитюк, А. Гладышева. - М.: Физкультура и спорт, 1989. - 176 с.

10. Озолин Н. Г. Настольная книга тренера / Н. Г. Озолин. - М.: Астрель, 2004. - 863 с.

11. Теория и методика фризического воспитания: учеб. для выс. учеб. заведений фриз. восп. и спорта / [Э. С. Вильчковский, Г. Г. Смолиус, Г. Ф. Шитикова и др.]; под ред. Т. Ю. Круцевич. - К.: Олимп. лит., 2003. - Т. 2. - 392 с.

12. Фомина E. В. Сенсомоторные асимметрии у спортсменов / Е. В. Фомина. - Омск: Изд-во Сиб ГУФК, 2003. - 150 c. вдосконалення силової підготовки, включення нових фрізичних вправ, які б сприяли зміцненню м'язового корсета, м'язів верхнього плечового пояса, зменшенню асиметричного впливу веслувального спорту та дозволяли б зберегти більш правильну поставу.

\section{References}

1. Gamburtsev V. A. Goniometry in the human body (dynamic somatometry) / V. A. Gamburtsev. - Moscow: Meditsina, 1972. - C. 6-12, 14-26.

2. Dorokhov R. N. Sports morphology: Study guide for high and intermediate educational establishments specialized in physical culture / R. Dorokhov, V. Guba. - Moscow: SportAkademPress, 2002. - 236 p.

3. Dubrovskii V. I. Sports physiology / V. I. Dubrovskii. Moscow: Humanitarian Publ. Center VLADOS, 2005. - 462 p.

4. Yegorov G. Ye. Classification of sports by the nature of their impact on the musculoskeletal system of athlete and some recommendations for the rational orientation of children in sport / G. Ye. Yegorov // Actualnye problemy travmatologii i ortopedii. - Leningrad, 1983. - P. 105-107.

5. Zabaluieva T. V. Prevention and correction of postural disturbances in students on various sports classes / T. V. Zabaluieva // Uchenye zapiski universiteta im. P. F. Lesgafta. - St. Petersburg, 2007. - Issue 9 (31). - P. 41-45.

6. Ivanova Ye. M. Anthropological features of the study of posture in children and adults: Authoreferat of dis. for the scientific degree of Cand. of biological sciences: speciality 03.03.02. "Anthropology in the biological sciences» / E. M. Ivanov. - Moscow, 2011. - 24 p.

7. Issurin V. B. Biomechanics of kayaking and canoeing / V. B. Issurin; ed. By V. M. Zatsiorskii. - Moscow: Fizkultura i sport, 1986. - 112 p.

8. Kashuba V. A. Biomechanics of posture / V. A. Kashuba. - Kyiv: Olympic Literature, 2003. - 280 p.

9. Nikitiuk B. A. Anatomy and sports morphology (practical course): Text guide for institutes of physical culture / B. A. Nikitiuk, A. Gladysheva. - Moscow: Fizkultura i sport, 1989. - 176 p.

10. Ozolin N. G. Handbook of the coach / N. G. Ozolin. - Moscow: Astrel, 2004. - 863 p.

11. Theory and methodology of physical education: Textbook for high educational establishments in physical education and sports / [E. S. Vilchkovskii, G. G. Smolius, G. F. Shitikova et al.]; ed. By T. Yu. Krutsevich. - Kyiv: Olympic Literature, 2003. - V. 2. -392 p.

12. Fomin E. V. Sensorimotor asymmetries in athletes / E. V. Fomin. - Omsk: Publishing House of the Siberian National University of Physical Culture, 2003. - 150 p.

Надійшла 02.04.2013 